\title{
EKSISTENSI PENYIDIK PEGAWAI NEGERI SIPIL (PPNS) DALAM PENEGAKAN HUKUM TERHADAP PELANGGARAN TATA RUANG
}

\author{
(Civil Servant Investigator (PPNS) Existence In Law Enforcement On Violation of Spatial Planning)
}

\author{
Sodikin \\ Fakultas Hukum Universitas Muhammadiyah Jakarta \\ Jl. KH. Ahmad Dahlan Ciputat Tangerang Selatan \\ Email: sodikinsadali68@gmail.com
}

Naskah diterima: 8 Juni 2017; revisi: 9 Agustus 2017; disetujui: 22 Agustus 2017

\begin{abstract}
Abstrak
Salah satu institusi yang diberi wewenang untuk melakukan penegakan hukum dalam bidang penataan ruang adalah Penyidik Pegawai Negeri Sipil (PPNS). Penyidik PPNS menjadi suatu institusi yang kewenangannya sama dengan penyidik Kepolisian RI dalam hal terjadinya tindak pidana penataan ruang yang oleh Undang-Undang telah diberikan kewenangannya untuk menyidik pelanggaran hukum tata ruang. Permasalahan yang diangkat pada penelitian ini terkait dengan eksistensi pelaksanaan tugas PPNS dalam melakukan penegakan hukum terhadap pelanggaran tata ruang. Dengan metode penelitian deskriptif normatif dapat disimpulkan bahwa pemerintah masih belum berupaya untuk menciptakan penataan ruang yang nyaman dan menumbuhkan kesadaran masyarakat, serta tidak adanya politik pemerintah dalam rangka memperbaiki dan memperkuat eksistensi PPNS Penataan Ruang. Oleh karena itu, perlu ada upaya oleh pemerintah untuk memperkuat eksistensi PPNS di bidang penataan ruang seperti membuat perangkat peraturan perundang-undangan lebih rinci, fasilitas yang memadai, program kerja yang terencana, mempersiapkan personil/anggota PPNS penataan ruang yang profesional. Kata Kunci: PPNS, penegakan hukum, tata ruang
\end{abstract}

\begin{abstract}
One of the institutions that is authorized enforce the spatial planning law is Civil Servant Investigator as regulated in Law Number 26 Year 2007. In the event of a spatial planning crime, which the law has given authority to the investigators to step in, The Civil Servant Investigator have same authority with the Police investigator.The problem addressed in this research is about the Civil Servant Investigators existence in law enforcement toward spatial planning violation. Using normative descriptive method, this research conclude that the government has not yet attempted to create a convenient spatial planning and cultivate public awareness. There is also no government's policy to improve and strengthen Civil Servant Investigators existence. Government needs to take action to strengthen the existence of Civil Servant Investigators in spatial planning law enforcement such as making more detailed regulations, providing adequate facilities, well-planned work program, and preparing professional Civil Servant Investigators personnel in the spatial planning law enforcement. Keywords: PPNS, law enforcement, spatial planning
\end{abstract}




\section{A. Pendahuluan}

Undang-Undang Nomor 26 Tahun 2007 tentang Penataan Ruang (UUPR) menjadi langkah awal dalam mewujudkan tata ruangyang selaras, harmonis dan berwawasan lingkungan termasuk upaya penegakan hukukmnya. Salah satu institusi yang diberi wewenang untuk melakukan penegakan hukum adalah Penyidik Pegawai Negeri Sipil (PPNS). Selanjutnya dalam UUPR juga mengatur bagian-bagian pokok diantaranya adalah pembagian wewenang antara pemerintah pusat, pemerintah daerah provinsi, dan pemerintah daerah kabupaten/ kota dalam penyelenggaraan penataan ruang untuk memberikan kejelasan tugas dan tanggung jawab masing-masing tingkat pemerintahan dalam mewujudkan ruang wilayah nasional yang selaras, harmonis, dan berwawasan lingkungan. Pembagian kewenangan juga mengatur upaya penegakan hukum dalam hal terjadi pelanggaran tata ruang, sehingga tidak ada salah paham dan ada koordinasi pembagian tugas kewenangan yang dilakukan oleh PPNS. Menurut Ridwan HR, bahwa tindakan hukum pemerintahan itu pada dasarnya adalah tindakan yang dilakukan dalam rangka melaksanakan ketentuan yang terdapat dalam peraturan perundang-undangan yang berlaku atau dalam rangka mengatur dan melayani kepentingan umum yang dikristalisasikan dalam peraturan perundang-undangan yang bersangkutan ${ }^{1}$.

Dalam kerangka otonomi daerah juga perlu adanya koordinasi dalam hal kewenangan antara pemerintah pusat, pemerintah daerah provinsi dan pemerintah daerah kabupaten/ kota, sehingga menghasilkan rencana umum tata ruang dan rencana rinci tata ruang. Oleh karena itu, pada tingkatan pemerintah daerah provinsi dan pemerintah daerah kabupaten/ kota dalam hal mengatur tata ruang melalui peraturan daerah yang seyogyanya saling bersesuaian dalam kerangka Negara Kesatuan Republik Indonesia. Dengan demikian, setiap daerah provinsi dan daerah kabupaten/kota masing-masing mempunyai peraturan daerah tentang penataan ruang dimana didalamnya terdapat institusi PPNS disetiap daerahnya masing-masing.

Keberadaan institusi PPNS disetiap daerah provinsi maupun kabupaten/kota tindak lain adalah untuk memperkuat kerangka otonomi daerah, dalam hal melaksanakan wewenang penyelenggaraan penataan ruang baik pemerintah provinsi maupun pemerintah kabupaten/kota. Di samping itu keberadaan institusi PPNS juga dalam rangka melaksanakan kegiatan pengaturan, pembinaan, pelaksanaan dan pengawasan serta penegakan hukum. Semua yang dilakukan merupakan bagian penataan ruang untuk seluruh wilayah Negara Kesatuan Republik Indonesia yang cakupannya meliputi penataan ruang wilayah nasional, penataan ruang wilayah provinsi, penataan ruang wilayah kabupaten dan penataan ruang wilayah kota.

Memperhatikan kewenangan pemerintah (baik pemerintah pusat, pemerintah provinsi maupun pemerintah kabupaten/kota) yang dimiliki melalui undang-undang, maka segala bentuk pembangunan harus memperhatikan pola tata ruang yang ada, sehingga pembangunan yang dimaksud berwawasan lingkungan (sustainable development). Di sinilah keberadaan institusi PPNS untuk 
mengawal setiap izin yang diberikan oleh pemerintah yang merupakan bentuk kewenangannya. Hal ini karena wewenang dalam memberikan izin suatu usaha dan/atau kegiatan dengan memperhatikan tata ruang daerah yang bersangkutan. Pemerintah (baik pemerintah pusat, pemerintah daerah provinsi maupun pemerintah kabupaten/kota) harus memperhatikan persyaratan yang ditentukan dalam peraturan perundang-undangan dalam memberikan perizinan yang berkaitan dengan pengelolaan lingkungan. Menurut Asep Warlan, Izin adalah suatu instrumen pemerintah yang bersifat yuridis preventif yang digunakan sebagai sarana hukum administrasi untuk mengendalikan perilaku masyarakat. ${ }^{2} \mathrm{Hal}$ ini sebagaimana ditentukan dalam Pasal 35 UUPR, yaitu: "Pengendalian pemanfaatan ruang dilakukan melalui penetapan peraturan zonasi, perizinan, pemberian insentif dan disinsentif, serta pengenaan sanksi".

Oleh karena adanya ketentuan sanksi (baik administratif maupun pidana) dalam hal kepatuhan terhadap ketentuan perizinan, maka dalam UUPR memberikan kewenangan kepada PPNS untuk melakukan tindakan penyidikan apabila terjadi tindak pidana di bidang penataan ruang. Institusi PPNS menjadi suatu institusi yang kewenangannya sama dengan penyidik Kepolisisan RI (Polri) dalam hal terjadinya tindak pidana tertentu yang dalam Undang-Undang tersebut memberikan kewenangan kepada PPNS. Tindak pidana pelanggaran penataan ruang ditujukan kapada siapa saja yang menurut UUPR dikenakan sanksi pidana termasuk juga pejabat pemerintah. Ketentuan tentang pejabat pemerintah dapat dikenakan sanksi pidana diatur dalam Pasal 73 UUPR ${ }^{3}$.

Memperhatikan beberapa hal tersebut, maka terdapat beberapa permasalahan yang kemudian dibahas dalam pembahasan selanjutnya, seperti perizinan yang tidak sesuai dan modus pelanggaran tata ruang, sehingga menyulitkan bagi Penyidik PPNS dalam melaksanakan kewenangannya. Permasalahan selanjutnya mengenai keberadaan PPNS, yang secara kelembagaan PPNS itu diangkat oleh pejabat yang secara administratif merupakan kewenangan pejabat yang bersangkutan, maka akan mendapatkan kesulitan bagi PPNS dalam melaksanakan kewenangannya. Selain masalah status kepegawaian dan kelembagaan, juga muncul seperti sarana dan prasarana, pembinaan kemampuan PPNS, program kerja, dan dukungan politik dari pemerintah. Hal inilah yang mempengaruhi eksistensi PPNS bidang penataan ruang dalam kapasitasnya sebagai penyidik menurut undang-undang. Permasalahan ini yang kemudian penulis akan menguraikannya lebih lanjut dalam pembahasan di bawah ini.

\footnotetext{
Asep Warlan Yusuf, dalam Juniarso Ridwan dan Achmad Sodik, Hukum Tata Ruang Dalam Konsep Kebijakan Otonomi Daerah, (Bandung: Nuansa, 2013), hlm. 106.

3 Ketentuan Pasal 73 Undang-Undang Nomor 26 Tahun 2007, yaitu:

- Setiap pejabat pemerintah yang berwenang yang menerbitkan izin tidak sesuai dengan rencana tata ruang sebagaimana dimaksud dalam Pasal 37 ayat (7), dipidana dengan pidana penjara paling lama 5 (lima) tahun dan denda paling banyak Rp500.000.000,00 (lima ratus juta rupiah).

- Selain sanksi pidana sebagaimana dimaksud pada ayat (1) pelaku dapat dikenai pidana tambahan berupa pemberhentian secara tidak dengan hormat dari jabatannya. ${ }^{6}$ Menurut Lawrence M. Friedman terdiri dari tiga komponen penting yaitu stuktur hukum (legal structure), substansi hukum (legal substance), dan budaya hukum (legal culture). Lawrence M. Friedman, American Law: An Introduction (New York: W.W.. Norton \& Company, 1984), hlm. 5.
} 


\section{B. Metode Penelitian}

Metode penelitian yang digunakan adalah metode deskriptif normatif yaitu menganalisis ketentuan tentang eksistensi PPNS di bidang penataan ruang dalam upaya penegakan hukum terhadap pelanggaran penataan ruang. Menurut Lili Rasjidi, "bahwa metode penelitian hukum yang original adalah metode penelitian hukum normatif" ${ }^{4}$ Menurut Soerjono Soekanto dan Sri Mamudji bahwa penelitian hukum normatif, sumber data yang dipergunakan adalah data sekunder. Data sekunder yang terdiri atas pertama, data hukum primer yang berupa peraturan perundang-undangan dan/ atau ketentuan hukum lainnya yang mengikat. Kedua data hukum sekunder yaitu berupa literatur, buku, hasil penelitian, makalah artikel, jurnal, dan internet. Ketiga, bahan hukum tersier yaitu berupa biografi, ensiklopedi dan kamus. ${ }^{5}$ Data yang diperoleh tersebut adalah data yang berupa kualitatif, sehingga teknis analisis yang digunakan adalah teknis analisis kualitatif, yaitu menganalisis dan menguraikan masalah yang ada secara kualitatif tentang eksistensi PPNS dalam penegakan hukum terhadap pelanggaran tata ruang.

\section{Pembahasan}

\section{Perizinan dan Pelanggaran Tata Ruang}

UUPR merupakan upaya pemerintah dalam menata ruang sesuai dengan peruntukannya. Menjelaskan kembali apa yang sudah ditentukan dalam pasal-pasal UUPR, dan perlu juga mengingatkan kembali penjelasan umum dalam UUPR poin 7 yang menyatakan:

"Pengendalian pemanfaatan ruang
tersebut dilakukan pula melalui perizinan
pemanfaatan ruang, pemberian insentif
dan disinsentif, serta pengenaan sanksi.
Perizinan pemanfaatan ruang dimaksudkan
sebagai upaya penertiban pemanfaatan
ruang sehingga setiap pemanfaatan ruang
harus dilakukan sesuai dengan rencana tata
ruang. Izin pemanfaatan ruang diatur dan
diterbitkan oleh Pemerintah dan pemerintah
daerah sesuai dengan kewenangannya
masing-masing. Pemanfaatan ruang yang
tidak sesuai dengan rencana tata ruang,
baik yang dilengkapi dengan izin maupun
yang tidak memiliki izin, dikenai sanksi
adminstratif, sanksi pidana penjara, dan/atau
sanksi pidana denda".

Selanjutnya juga dikatakan bahwa:

"Pengenaan sanksi, yang merupakan salah satu upaya pengendalian pemanfaatan ruang, dimaksudkan sebagai perangkat tindakan penertiban atas pemanfaatan ruang yang tidak sesuai dengan rencana tata ruang dan peraturan zonasi. Dalam UndangUndang ini pengenaan sanksi tidak hanya diberikan kepada pemanfaat ruang yang tidak sesuai dengan ketentuan perizinan pemanfaatan ruang, tetapi dikenakan pula kepada pejabat pemerintah yang berwenang yang menerbitkan izin pemanfaatan ruang yang tidak sesuai dengan rencana tata ruang".

Penjelasan umum UUPR tersebut, diperlukan guna memberi kepastian hukum dan kewenangan setidaknya sebagai pegangan dalam penyelenggaraan penataan ruang, baik penataan ruang pada tingkat nasional, provinsi, maupun pada tingkatan kabupaten/ kota. ${ }^{6}$ Dasar aturan yang jelas tersebut bertolak 
belakang dengan kenyataan dalam praktek, di beberapa daerah seringkali ditemui adanya pelanggaran pemanfaatan ruang antara lain pemanfaatan ruang yang tidak sesuai izin dan pemanfaatan ruang yang tidak sesuai peruntukannya sebagaimana dalam rencana tata ruang wilayah. Pada umumnya di daerahdaerah dalam perizinan sudah sesuai dengan peruntukannya, namun mayoritas belum disertai dengan ljin Mendirikan Bangunan (IMB). Secara implementatif, siapapun masyarakat yang hendak melakukan pemanfaatan ruang atau mendirikan bangunan di atas sebuah lahan harus memiliki izin dari pemerintah provinsi atau pemerintah kabupaten/kota. Kondisi yang berkembang saat ini tidak sedikit ljin Mendirikan Bangunan (IMB) yang sesungguhnya telah cacat karena berisikan izin pendirian untuk satu atau lebih bangunan dengan peruntukan yang tidak sesuai dengan rencana tata ruang wilayahnya masing-masing. ${ }^{7}$

Seiring upaya untuk menciptakan ruang yang nyaman dan menumbuhkan kesadaran masyarakat terhadap ketentuan yang terdapat dalam UUPR, diharapkan penyelenggaraan penataan ruang harus sesuai dengan aturan teknis yang ada. Maksudnya untuk mengurangi dampak yang besar dari pelanggaran penataan ruang. Oleh karena itu, penegakan hukum bagi pelanggaran peruntukan ruang yang bisa mengakibatkan bencana bagi daerah sekitarnya harus terus dilakukan. Hal ini untuk menunjukkan niat baik pemerintah dan tidak adanya kesan yang kurang baik bahwa peraturan hanya sebatas kebijakan yang dalam implementasinya sering tidak sesuai. Menurut Ahmad Sukardja, tercapai tidaknya tujuan hukum terletak pada pelaksanaan hukum itu, ketertiban dan ketenteraman masyarakat hanya dapat diwujudkan secara nyata bila hukum dilaksanakan dan ditegakkan dengan baik. ${ }^{8}$

Dalam hal-hal tertentu, keputusan tentang izin juga penting bagi pihak yang berkepentingan. Artinya pihak pemerintah selaku pemberi izin harus pula mempertimbangkan kepentingan pihak ketiga yang mungkin memiliki keterkaitan dengan penggunaan izin tersebut. ${ }^{9}$ Oleh karena itu, perizinan pemanfaatan ruang dimaksudkan sebagai upaya penertiban pemanfaatan ruang sehingga setiap pemanfaatan ruang harus dilakukan sesuai dengan rencana tata ruang, sehingga masyarakat sebagai pihak ketiga perlu dilibatkan, karena masyarakatlah yang akan terkena dampaknya.

Dengan demikian, penataan ruang yang baik menyangkut seluruh aspek kehidupan, sehingga masyarakat perlu mendapat akses dalam proses perencanaan penataan ruang. Pelibatan masyarakat merupakan salah satu upaya peran serta masyarakat dalam rangka melestarikan lingkungan hidup. Selanjutnya, upaya perencanaan pelaksanaan tata ruang yang bijaksana adalah kunci dalam pelaksanaan tata ruang agar tidak merusak lingkungan hidup, dalam konteks penguasaan negara atas dasar sumber daya alam, melekat di dalam kewajiban pemerintah untuk melindungi, melestarikan dan memulihkan lingkungan hidup secara utuh. Artinya, aktivitas pembangunan yang dihasilkan dari perencanaan tata ruang pada umumnya

\footnotetext{
Dapat juga baca: Dedi Gustian, dkk, dalam Politik Ruang dan Perlawanan: Kisah Konflik Atas Ruang Pada Tingkat Lokal, Bogor, Jaringan Kerja Pemetaan Partisipatif, 2014.

8 Ahmad Sukardja, Hukum Tata Negara dan Hukum Administrasi Negara Dalam Perspektif Fikih Siyasah, (Jakarta: Sinar Grafika, 2012), hlm. 242.

9 Ridwan HR, Op.cit, hlm. 220.
} 
bernuansa pemanfaatan sumber daya alam tanpa merusak lingkungan.

Izin merupakan berkenaan dengan menyelenggarakan peraturan dalam hal konkreto, berfungsi selaku ujung tombak instrumen hukum sebagai pengarah, perekayasa, dan perancang masyarakat adil dan makmur itu dijelmakan. ${ }^{10}$ Oleh karena itu, izin pemanfaatan ruang yang diatur dalam peraturan perundangundangan dan diterbitkan oleh Pemerintah (baik pemerintah pusat, pemerintah provinsi maupun pemerintah kabupaten/kota) harus sesuai dengan kewenangannya masing-masing. Akan tetapi, muncullah kritik dari masyarakat dalam penataan ruang, karena rencana tata ruang menurut peraturan perundang-undangan belum cukup efektif sebagai alat kendali penyimpangan, dikarenakan penyimpangan atau pelanggaran tata ruang terjadi pada hampir semua kota dan daerah di Indonesia. Banyak faktor yang menyebabkan terjadinya pelanggaran tata ruang di antaranya lemahnya pengawasan dan penertiban, tidak adanya sinkronisasi perizinan, sehingga prosedur perizinan berbelit-belit, perilaku KKN (korupsi, kolusi dan nepotisme) oknum pejabat, dan ketidakadilan rencana kota. ${ }^{11}$

Lemahnya pengawasan dan penertiban sebagai fungsi pengawasan dan penertiban mengakibatkan terjadinya pelanggaran tata ruang, karena memang ada keterbatasan sumber daya manusia yang bertugas untuk mengawasi dan menertibkan terjadinya pelanggaran tata ruang. Pemerintah terutama adalah pemerintah daerah tidak mampu menyediakan sumber daya manusia yang mampu mengawasi dan menertiban apabila terjadi penyimpangan tata ruang. Pelanggaran tata ruang juga terjadi akibat tidak adanya sinkronisasi perizinan, karena di antara instansi pemerintah tidak saling memahami tugas dalam suatu pemerintahan dan juga tidak adanya pedoman rencana tata ruang sebagai pedoman dalam menerbitkan perizinan. Begitu juga prosedur perizinan yang berbelit-belit, lambat dan biaya tinggi mendorong masyarakat untuk melakukan berbagai cara membangun tanpa izin, yang tidak sesuai dengan rencana tata ruang. ${ }^{12}$

Selain itu, masalah bangsa yang krusial adalah sikap aparat pemerintah yang koruptif, sehingga aparat yang diserahi tanggung jawab dalam penataan ruang banyak yang bermental koruptif. Mereka secara sadar melakukan manipulasi terhadap rencana tata ruang melalui perizinan yang salah, bahkan ini dilakukan oleh kepala daerahnya. ${ }^{13}$ Berbagai cara dilakukan antara lain dengan memanipulasi data lokasi yang dimohon dengan mengubah kordinat situasi terukur, manipulasi perizinan yang diterbitkan dengan mengubah peruntukan, menerbitkan izin yang tidak sesuai blue print rencana tata ruang dan lain sebagainya untuk lokasi-lokasi yang bermasalah. Demikian juga dengan aparat pengawasan yang dengan sengaja membiarkan terjadinya berbagai macam pelanggaran dengan mengharap dapat

10 Hasni, Hukum Penataan Ruang dan Penatagunaan Tanah, Dalam Konteks UUPA, UUPR, UUPLH, (Jakarta: Rajawali Press, 2013), hlm. 13.

11 Dedi Gustian, Loc cit.

12 Ibid.

13 Raflis, "Tata Ruang dan Korupsi”, Transparency International Indonesia, https://advokasitataruang.files. wordpress.com/2011/09/tata-ruang-dan-korupsi.pdf (diakses 20 Juli 2017). 
memperoleh berbagai imbalan. ${ }^{14} \mathrm{Hal}$ inilah yang kemudian menyebabkan ketidakadilan rencana tata kota bagi masyarakat karena adanya manipulasi yang dilakukan oleh oknum aparat pemerintahan.

Oleh karena adanya pelanggaran atau penyimpangan tata ruang, maka perlu adanya pengenaan sanksi, dan pengenaan sanksi merupakan salah satu upaya pengendalian pemanfaatan ruang. Artinya sebagai perangkat tindakan penertiban atas pemanfaatan ruang yang tidak sesuai dengan rencana tata ruang dan peraturan zonasi. Menurut Philipus $M$ Hadjon penempatan sanksi dalam suatu aturan hukum, merupakan bagian penutup yang sangat penting dalam setiap peraturan perundang-undangan termasuk dalam aturan hukum administrasi. Pada umumnya tidak ada gunanya memasukkan aturan-aturan hukum tentang kewajiban-kewajiban atau laranganlarangan bagi para warga dalam aturan hukum bidang administrasi negara, manakala aturanaturan mengenai tingkah laku tidak dapat dipaksakan secara tegas oleh aparat pemerintah atau lembaga/instansi maupun pejabat yang berwenang untuk itu ${ }^{15}$.

Akan tetapi, pada dasarnya pengenaan sanksi administratif kepada pelanggar pemanfaatan ruang mempunyai fungsi sebagai:

a. Perangkat untuk mencegah, membatasi pertumbuhan atau mengurangi kegiatan yang tidak sejalan dengan rencana tata ruang; dan

b. Penertiban pemanfaatan ruang yang tidak sesuai dengan rencana tata ruang. ${ }^{16}$

Sama halnya dengan sanksi administratif, sanksi pidana juga diterapkan sebagai pelajaran atau efek jera bagi pelanggar. Pengenaan sanksi pidana terhadap:

a. pemanfaatan ruang yang tidak sesuai dengan rencana struktur ruang dan pola ruang wilayah nasional;

b. pelanggaran ketentuan arahan peratuan zonasi sistem nasional;

c. pemanfaatan ruang tanpa izin pemanfaatan ruang yang diterbitkan berdasarkan RTRWN;

d. pemanfaatan ruang tidak sesuai dengan izin pemanfaatan ruang yang diterbitkan berdasarkan RTRWN;

e. pelanggaran ketentuan yang ditetapkan dalam persyaratan izin pemanfaatan ruang yang diterbitkan berdasarkan RTRWN;

f. pemanfataan ruang yang menghalangi akses terhadap kawasan yang oleh peraturan perundang-undangan dinyatakan sebagai milik umum; dan/atau

g. pemanfaatan ruang dengan izin yang diperoleh dengan prosedur yang tidak benar. ${ }^{17}$

14 Ismail Zubir, "Penyimpangan Tata Ruang", KALPATARU, https://imazu.wordpress.com/2008/01/09/ penyimpangan-tata-ruang/ (diakses 19 Mei 2017).

15 Philipus M Hadjon, Pengantar Hukum Administrasi Indonesia, (Yogyakarta: Gadjah Mada University Press, 2002), hlm. 245, sebagaimana dikutip oleh Bahder Johan Nasution, "Upaya Penerapan Sanksi Administratif Dan Perizinan Sebagai Pembatasan Terhadap Kebebasan Bertindak", (dalam Jurnal Ilmu Syariah dan Hukum AsySyir'ah, Vol. 48, No. 1, Juni 2014), hlm. 217.

16 Indonesian Institute for Infrastructure Studies, "Ketentuan Pengendalian Pemanfaatan Ruang Wilayah Kabupaten", Indonesian Institute for Infrastructure Studies, http://www.penataanruang.com/pengendalianruang2.html (diakses 21 Mei 2017).

17 Indonesian Institute for Infrastructure Studies, “Arahan Sanksi”, Indonesian Institute for Infrastructure Studies, http://www.penataanruang.com/sanksi.html (diakses 21 Mei 2017). 


\section{Eksistensi PPNS Dalam Penegakan Hukum}

Terdapat beberapa peraturan perundangundangan yang mengatur keberadaan PPNS, di antaranya Pasal 6 ayat (1) huruf b KUHAP menyatakan, bahwa: "penyidik adalah pejabat pegawai negeri sipil tertentu yang diberi wewenang khusus oleh undang-undang" Penjelasannya: "kedudukan dan kepangkatan penyidik yang diatur dalam peraturan pemerintah diselaraskan dan diseimbangkan dengan kedudukan dan kepangkatan penuntut umum dan hakim peradilan umum". Pasal 1 angka 11 Undang-Undang Nomor 2 Tahun 2002 tentang Kepolisian Negara Republik Indonesia juga menjelaskan tentang keberadaan PPNS, yaitu: "Penyidik Pegawai Negeri Sipil adalah pejabat pegawai negeri sipil tertentu yang berdasarkan peraturan perundang-undangan ditunjuk selaku penyidik dan mempunyai wewenang untuk melakukan penyidikan tindak pidana dalam lingkup undang-undang yang menjadi dasar hukumnya masingmasing". Begitu juga dalam Pasal 1 angka 5 Peraturan Pemerintah Nomor 43 tahun 2012 tentang Tata Acara Pelaksanaan Koordinasi, Pengawasan, dan Pembinaan Teknis Terhadap Kepolisian Khusus, Penyidik Pegawai Negeri Sipil dan Bentuk-bentuk Pengamanan Swakarsa, Penyidik Pegawai Negeri Sipil yang selanjutnya disingkat PPNS adalah Pejabat Pegawai Negeri Sipil tertentu yang berdasarkan peraturan perundang-undangan ditunjuk selaku penyidik dan mempunyai wewenang untuk melakukan penyidikan tindak pidana dalam lingkup undang- undang yang menjadi dasar hukumnya masingmasing. Menurut komentar KUHAP dalam penjelasannya menyatakan "pejabat pegawai negeri sipil tertentu yang diberi wewenang sebagai penyidik oleh undang-undang khusus itu misalnya saja polisi kehutanan, pejabat bea dan cukai, pejabat imigrasi dan lain sebagainya". ${ }^{18}$ Koesnadi Hardjasoemantri juga menyatakan, bahwa tindak pidana di bidang lingkungan hidup menyangkut aspek yang sering bersifat sangat teknis, sehingga memerlukan keahlian tertentu untuk melakukan penyidikan yang sukar diharapkan dari para penyidik pejabat Polri, oleh karena itu diperlukan PPNS sebagaimana dimaksud dalam KUHAP. ${ }^{19}$

Selanjutnya dalam Undang-Undang Nomor 23 Tahun 20014 tentang Pemerintah Daerah terutama dalam Pasal 257 Undang-Undang Nomor 23 Tahun 2014 tentang Pemerintahan Daerah menyebutkan adanya PPNS, yaitu:

(1) Penyidikan terhadap pelanggaran atas ketentuan Perda dilakukan oleh pejabat penyidik sesuai dengan ketentuan peraturan perundang-undangan.

(2) Selain pejabat penyidik sebagaimana dimaksud pada ayat (1) dapat ditunjuk penyidik pegawai negeri sipil yang diberi tugas untuk melakukan penyidikan terhadap pelanggaran atas ketentuan Perda sesuai dengan ketentuan peraturan perundangundangan.

(3) Penyidik pegawai negeri sipil sebagaimana dimaksud pada ayat (2) menyampaikan hasil penyidikan kepada penuntut umum dan berkoordinasi dengan penyidik kepolisian setempat.

18 M. Karjadi dan R. Soesilo, Kitab Undang-Undang Hukum Acara Pidana dengan Penjelasan Resmi dan Komentar, (Bogor: Politeia, 1997), hlm. 16.

19 Koesnadi Hardjasoemantri, Hukum Tata Lingkungan, Edisi VIII (Yogyakarta, Gadjah Mada University Press, 2006), hlm. 433. 
(4) Penuntutan terhadap pelanggaran atas ketentuan Perda dilakukan oleh penuntut umum sesuai dengan ketentuan peraturan perundang-undangan.

Undang-undang Nomor 23 Tahun 2014 tersebut telah memberikan ruang untuk dibentuknya PPNS yang secara khusus di tempatkan di daerah dan diberi tugas melakukan penyidikan terhadap kemungkinan terjadinya tindak pidana sebagaimana diatur dalam suatu peraturan daerah. Selain itu, eksistensi PPNS di daerah secara spesifik diatur dalam Pasal 1 angka 6 Peraturan Pemerintah Nomor 58 Tahun 2010 tentang Perubahan Atas Peraturan Pemerintah Nomor 27 Tahun 1983 Tentang Pelaksanaan Kitab Undang-Undang Hukum Acara Pidana. Dalam Peraturan Pemerintah tersebut disebutkan bahwa PPNS adalah pegawai negeri sipil tertentu sebagaimana dimaksud dalam KUHAP, baik yang berada di pusat maupun daerah yang diberi wewenang khusus oleh undang-undang.

Landasan pengorganisasian PPNS di daerah sebagaimana disebut dalam Peraturan Pemerintah Nomor 58 Tahun 2010 lebih lanjut diatur dalam Peraturan Menteri Dalam Negeri No. 41 Tahun 2010 tentang Organisasi dan Tata Kerja Kementerian Dalam Negeri. Keberadaan PPNS secara khusus disebutkan dalam Bagian Keenam Direktorat Polisi Pamong Praja dan Perlindungan Masyarakat. Pasal 315 huruf e Peraturan Menteri Dalam Negeri No. 41 Tahun 2010 menyebutkan bahwa salah satu fungsi Direktorat Polisi Pamong Praja dan Perlindungan Masyarakat adalah penyiapan perumusan kebijakan dan fasilitasi pembinaan PPNS. Subdirektorat PPNS menyelenggarakan fungsi: penyiapan bahan perumusan kebijakan, fasilitasi dan koordinasi serta monitoring dan evaluasi penyelenggaraan pembinaan operasional penyidik pegawai negeri sipil, dan mempersiapkan bahan perumusan kebijakan, fasilitasi, koordinasi, monitoring dan evaluasi, pembinaan dan administrasi aparatur penyidik pegawai negeri sipil. Begitu juga dalam Pasal 316 huruf d Peraturan Menteri Dalam Negeri No. 41 Tahun 2010 mengatur bahwa PPNS sebagai salah satu subdirektorat di antara lima subdirektorat yang berada di bawah Direktorat Polisi Pamong Praja dan Perlindungan Masyarakat.

Penyebutan PPNS secara langsung sebagai PPNS Daerah yaitu terdapat dalam Pasal 1 angka 1 Keputusan Menteri Dalam Negeri No. 7 Tahun 2003 tentang Pedoman Operasional Penyidik Pegawai Negeri Sipil Daerah Dalam Penegakan Peraturan Daerah. Dalam ketentuan tersebut mengatur bahwa PPNS Daerah adalah Pejabat Pegawai Negeri Sipil tertentu di lingkungan pemerintahan daerah yang diberi wewenang khusus oleh undang-undang untuk melakukan penyidikan terhadap pelanggaran peraturan daerah.

Sebagaimana dijelaskan dalam Pasal 6 ayat (1) huruf b KUHAP tersebut telah dipersyaratkan untuk menjadi PPNS haruslah seorang yang bekerja sebagai pegawai negeri sipil, syarat yang kedua adalah dalam institusinya harus ada peraturan perundang-undangan yang mengikat kepada publik tentang pengaturan suatu yang jelas. Misalnya Dinas Perikanan, dalam dinas tersebut harus ada peraturan perundangundangan yang ditaati oleh masyarakat umum dan dinas lainnya yang kewenangannya diatur secara tersendiri dengan peraturan perundang-undangan. ${ }^{20}$ Dengan demikian,

20 Hartono, Penyidikan dan Penegakan Hukum Pidana Melalui Pendekatan Hukum Progresif, (Jakarta: Sinar Grafika, 2010), hlm. 54. 
di bidang tata ruang dengan merujuk Pasal 1 angka 11 Undang-Undang Nomor 2 Tahun 2002 tentang Kepolisian Negara Republik Indonesia, bahwa PPNS adalah pejabat pegawai negeri sipil tertentu yang berdasarkan peraturan perundang-undangan ditunjuk selaku penyidik dan mempunyai wewenang untuk melakukan penyidikan tindakan pidana dalam lingkup undang-undang yang menjadi dasar hukumnya, maka di bidang penataan ruang sesuai dengan UUPR adalah PPNS penataan ruang.

Berdasarkan tindak pidana dalam lingkup undang-undang yang menjadi dasar hukum masing-masing, maka dalam tindak pidana bidang penataan ruang sebagaimana ditentukan dalam UUPR, maka undang-undang tersebut mengenal PPNS di bidang penataan ruang. Dikatakan demikian, karena eksistensi PPNS menurut UUPR lebih spesifik bertugas dan berwenang melakukan kegiatannya sebagaimana diatur dalam Pasal 68 UUPR, yaitu:

(1) Selain pejabat penyidik kepolisian negara Republik Indonesia, pegawai negeri sipil tertentu di lingkungan instansi pemerintah yang lingkup tugas dan tanggung jawabnya di bidang penataan ruang diberi wewenang khusus sebagai penyidik untuk membantu pejabat penyidik Kepolisian Negara Republik Indonesia sebagaimana dimaksud dalam Kitab Undang-Undang Hukum Acara Pidana.

(2) Penyidik pegawai negeri sipil sebagaimana dimaksud pada ayat (1) berwenang:

a. melakukan pemeriksaan atas kebenaran laporan atau keterangan yang berkenaan dengan tindak pidana dalam bidang penataan ruang;

b. melakukan pemeriksaan terhadap orang yang diduga melakukan tindak pidana dalam bidang penataan ruang; c. meminta keterangan dan bahan bukti dari orang sehubungan dengan peristiwa tindak pidanadalam bidang penataan ruang;

d. melakukan pemeriksaan atas dokumendokumen yang berkenaan dengan tindak pidana dalambidang penataan ruang;

e. melakukan pemeriksaan di tempat tertentu yang diduga terdapat bahan bukti dan dokumen lain serta melakukan penyitaan dan penyegelan terhadap bahan dan barang hasil pelanggaran yang dapat dijadikan bukti dalam perkara tindak pidana dalam bidang penataan ruang; dan

f. meminta bantuan tenaga ahli dalam rangka pelaksanaan tugas penyidikan tindak pidana dalam bidang penataan ruang.

(3) Penyidik pegawai negeri sipil sebagaimana dimaksud pada ayat (1) memberitahukan dimulainya penyidikan kepada pejabat penyidik kepolisian negara Republik Indonesia.

(4) Apabila pelaksanaan kewenangan sebagaimana dimaksud pada ayat (2) memerlukan tindakan penangkapan dan penahanan, penyidik pegawai negeri sipil melakukan koordinasi dengan pejabat penyidik kepolisian negara Republik Indonesia sesuai dengan ketentuan peraturan perundang-undangan.

(5) Penyidik pegawai negeri sipil sebagaimana dimaksud pada ayat (1) menyampaikan hasil penyidikan kepada penuntut umum melalui pejabat penyidik kepolisian negara Republik Indonesia.

(6) Pengangkatan pejabat penyidik pegawai negeri sipil dan tata cara serta proses 
penyidikan dilaksanakan sesuai dengan ketentuan peraturan perundang-undangan.

Ketentuan lebih khusus yang mengatur PPNS bidang penataan ruang diatur dalam Peraturan Menteri Pekerjaan Umum Nomor 13/PRT/M/2009 tentang Penyidik Pegawai Negeri Sipil Penataan Ruang. Menurut Permen tersebut, bahwa PPNS Penataan Ruang merupakan Pegawai Negeri Sipil tertentu di lingkungan Direktorat Jenderal Penataan Ruang Departemen Pekerjaan Umum, Pegawai Negeri Sipil tertentu di lingkungan pemerintah daerah provinsi dan pemerintah daerah kabupaten/ kota yang membidangi urusan penataan ruang di daerah yang mengemban tugas, fungsi dan wewenang sesuai dengan ketentuan Pasal 6 ayat (1) huruf b KUHAP dan Pasal 68 ayat (1) UU No. 26 Tahun 2007tentang Penataan Ruang.

Peraturan perundang-undangan tersebut tampak jelas bahwa eksistensi PPNS dalam proses penyidikan adalah membantu pihak Kepolisian dalam hal terjadi tindak pidana di bidang tertentu dalam hal ini di bidang penataan ruang. Diberikannya wewenang untuk melaksanakan tugas penyidikan kepada PPNS memudahkan dalam pengungkapan suatu tindak pidana mengingat banyaknya kendala yang dihadapi oleh aparat kepolisian dalam melakukan penyidikan, seperti kualitas dan kuantitas sumber daya manusia, saranaprasarana pendukung, serta anggaran. Oleh karena itu, dilibatkannya PPNS, yang sejatinya merupakan bagian dari institusi eksekutif, tetapi dalam proses penyidikan tindak pidana lebih banyak dilatarbelakangi kondisi faktual di lingkungan internal Polri karena Polri masih memiliki berbagai kekurangan. Maka PPNS merupakan penyidik yang berasal dari pegawai negeri sipil untuk melakukan penyidikan tindak pidana tertentu (dalam hal ini di bidang penataan ruang). Akan tetapi, dalam kenyataan PPNS juga mengalami hal yang sama terutama mengenai sumber daya manusia karena tidak adanya pembinaan yang baik, anggaran yang terbatas dan tidak ada koordinasi yang baik antara instansi penyidik Polri dengan PPNS, program kerja yang tidak jelas serta faktor kelembagaan PPNS itu sendiri yang tidak ada.

Namun demikian, Pasal 68 ayat (1) UUPR jo. Peraturan Menteri Pekerjaan Umum Nomor 13/PRT/M/ 2009 tentang Penyidik Pegawai Negeri Sipil Penataan Ruang, yang mengatur keberadaan Penyidik Pegawai Negeri Sipil sebagai penyidik dalam hal terjadinya tindak pidana di bidang penataan ruang. Maka dalam kerangka sistem peradilan pidana (criminal justice system), peran aparatur penegak hukum, khususnya PPNS sangat strategis. PPNS merupakan pintu gerbang utama dimulainya tugas pencarian kebenaran materiil karena melalui proses penyidikan sejatinya sebagai upaya penegakan hukum terhadap penataan ruang mulai dilaksanakan. menurut Andi Hamzah, menyidik berarti pemeriksaan permulaan oleh pejabat-pejabat yang untuk itu ditunjuk oleh undang-undang segera setelah mereka dengan jalan apa pun mendengar khabar yang sekadar beralasan bahwa ada terjadi sesuatu pelanggaran hukum. ${ }^{21}$

Sebagaimana dijelaskan dalam Pasal 68 ayat (1) UUPR yang mengamanatkan dibentuknya PPNS Penataan Ruang yang mempunyai tugas dan kewenangan untuk melakukan penegakan hukum terhadap pelanggaran pemanfaatan

21 Andi Hamzah, Hukum Acara Pidana Indonesia, (Jakarta: Sinar Grafika, 2008), hlm. 120. 
ruang yang berindikasi pidana melalui kegiatan penyidikan tindak pidana penataan ruang. Bahkan Peraturan Menteri Pekerjaan Umum Nomor 13/PRT/M/ 2009 tentang Penyidik Pegawai Negeri Sipil Penataan Ruang memberikan pengaturan khusus bagi PPNS yang diberi tugas dan kewenangan khusus dalam hal terjadinya tindak pidana di bidang penataan ruang.

Mengenai pengangkatan PPNS, maka pengangkatan fungsional ditujukan khusus untuk melakukan penyidikan pada bidangbidang tertentu (penataan ruang) sesuai dengan undang-undang yang menjadi dasar hukum pelaksanaan tugasnya. Sebagai dasar hukum dalam hal pengangkatan PPNS, yaitu melalui Peraturan Menteri Hukum dan HAM No. M.HH.01.AH.09.01 TAHUN 2011 Tentang Tata Cara Pengangkatan, Pemberhentian, Mutasi, Dan Pengambilan Sumpah atau Janji Pejabat Penyidik Pegawai Negeri Sipil, Dan Bentuk, Ukuran, Warna, Format, Serta Penerbitan Kartu Tanda Pengenal Pejabat Penyidik Pegawai Negeri Sipil. Ketentuan dalam peraturan Menteri Hukum dan HAM tersebut mengatur syarat-syarat untuk menjadi PPNS di lingkungan instansi masing-masing termasuk di dalamnya pada lingkungan instansi penataan ruang. Melihat peraturan demikian, maka yang menjadi wewenang pengangkatan PPNS dilakukan oleh Menteri Hukum dan HAM, akan tetapi kewenangan pengangkatan tersebut atas usul pimpinan kementerian atau lembaga pemerintah lainnya yang membutuhkan adanya PPNS.

\section{Upaya Penegakan Hukum oleh PPNS}

Penegakan hukum terhadap pelanggaran atau penyimpangan pemanfaatan ruang merupakan salah satu pilar penting untuk mewujudkan tertib penataan ruang. Menurut Bagir Manan, keberhasilan suatu peraturan perundang-undangan bergantung pada penerapan dan penegakannya, apabila penegakan hukum tidak berjalan dengan baik, peraturan perundang-undangan bagaimanapun sempurnanya tidak atau kurang memberikan arti sesuai dengan tujuannya, penegakan hukum merupakan dinamisator peraturan perundangundangan ${ }^{22}$. Hal ini berarti keberadaan PPNS Penataan Ruang di tingkat pusat, provinsi, dan kabupaten/kota diperlukan sekali dalam rangka penegakan hukum demi tertib penataan ruang untuk mendorong setiap upaya pemanfaatan ruang sesuai dengan Rencana Tata Ruang Wilayah Nasional (RTRW) sebagaimana dikehendaki dalam Pembukaan UUD 1945.

Secara prinsip sistem penataan ruang sebagaimana djelaskan di atas terbagi menjadi 3 (tiga) bagian, yakni: (1) perencanaan; (2) pengelolaan dan pemanfaatan ruang; dan (3) pengendalian dan penertiban tata ruang. Terkait dengan hal tersebut, dalam rangka menyelenggarakan penataan ruang yang transparan, efektif, aman, nyaman, produktif, dan berkelanjutan, maka kehadiran perangkat aturan dan perangkat lembaga penegakan hukum dalam bidang penataan ruang sangat diperlukan. PPNS sebagai salah satu pilar perangkat dalam penegakan hukum di bidang penataan ruang membutuhkan legalitas dalam struktur kelembagaan dalam sistem peradilan pidana. 
Harapan masyarakat untuk memperoleh jaminan dan kepastian hukum masih sangat terbatas. Penegakan hukum dan pelaksanaan hukum belum berjalan sesuai dengan prinsipprinsipkeadilan dan kebenaran ${ }^{23}$. Lahirnya UUPR, menjadi langkah awal dalam mewujudkan tata ruang yang selaras, harmonis dan berwawasan lingkungan. Untuk mewujudkannya, maka Undang-undang ini mengatur bagian-bagian pokok, di antaranya:

a. Pembagian wewenang antara pemerintah, pemerintah provinsi, dan pemerintah kabupaten/kota dalam penyelenggaraan penataan ruang untuk memberikan kejelasan tugas dan tanggung jawabnya masing-masing tingkat pemerintahan dalam mewujudkan ruang wilayah nasional yang aman, nyaman, produktif, dan berkelanjutan;

a. Pengaturan penataan ruang yang dilakukan melalui penetapan peraturan perundang-undangan termasuk pedoman bidang penataan ruang sebagai acuan penyelenggaraan penataan ruang;

b. pengaturan penataan ruang yang dilakukan melalui penetapan peraturan perundang-undangan termasuk pedoman bidang penataan ruang sebagai acuan penyelenggaraan penataan ruang;

c. pembinaan penataan ruang melalui berbagai kegiatan untuk meningkatkan kinerja penyelenggaraan penataan ruang;

d. pelaksanaan penataan ruang yang mencakup perencanaan tata ruang, pemanfaatan ruang, dan pengendalian pemanfaatan ruang pada semua tingkat pemerintahan;

e. pengawasan penataan ruang yang mencakup pengawasan terhadap kinerja pengaturan, pembinaan, dan pelaksanaan penataan ruang, termasuk pengawasan terhadap kinerja pemenuhan standar pelayanan minimal bidang penataan ruang melalui kegiatan pemantauan, evaluasi, dan pelaporan;

f. hak, kewajiban, dan peran masyarakat dalam penyelenggaraan penataan ruang untuk menjamin keterlibatan masyarakat, termasuk masyarakat adat dalam setiap proses penyelenggaraan penataan ruang;

g. penyelesaian sengketa, baik sengketa antar daerah maupun antar pemangku kepentingan lain secara bermartabat;

h. penyidikan, yang mengatur tentang penyidik pegawai negeri sipil beserta wewenang dan mekanisme tindakan yang dilakukan;

i. ketentuan sanksi administratif dan sanksi pidana sebagai dasar untuk penegakan hukum dalam penyelenggaraan penataan ruang. ${ }^{24}$

Ketentuan tersebut menunjukkan perlunya penegakan hukum terhadap pelaku tindak pidana penataan ruang agar terwujud apa yang dikehendaki oleh UUPR. Dalam melaksanakan dan upaya penegakan hukum terhadap tindak pidana penataan ruang, maka UUPR juga mengatur tentang kedudukan dan fungsi Penyidik Pegawai Negeri Sipil Penataan Ruang (PPNS-PR) sebagai mitra penyidik Kepolisian Republik Indonesia sebagaimana diatur dalam Pasal 68 UUPR dan sudah dijelaskan di atas. Pasal 68 UUPR tersebut kemudian secara organik dijelaskan lebih rinci lagi dalam Permen PU No. 13/PRT/M/2009 tentang Penyidik Pegawai Negeri Sipil Penataan Ruang, yang di dalamnya

23 Erman Rajagukguk., "Perlu Pembaharuan Hukum dan Profesi Hukum", (Pidato Pengukuhan Sebagai Guru Besar Hukum, Suara Pembaruan), hlm. 11.

24 Penjelasan Umum Poin 9 Undang-Undang Nomor 26 Tahun 2007. 
mengatur pedoman pelaksanaan tugas Penyidik Pegawai Negeri Sipil Penataan Ruang dalam melaksanakan tugas penyidikan tindak pidana di bidang Penataan Ruang dan tercapainya tujuan untuk memperoleh ketepatan, kecepatan dan keseragaman dalam pelaksanaan dan penatausahaan penyidikan, serta sesuai dengan mekanisme yang ditetapkan di dalam KUHAP dan peraturan perundang-undangan lainnya.

Eksistensi PPNS-PR menurut peraturan perundang-undangan telah menunjukkan keberadaan PPNS yang diperlukan dalam penegakan hukum di bidang penataan ruang. Data yang dihimpun oleh Kementerian Pekerjaan Umum dan Penataan Ruang telah lahir ratusan PPNS baik di pusat maupun di daerah yang telah dilantik sebagai PPNS-PR. Akan tetapi, kenyataannya dengan segala upaya penegakan hukum terhadap tindak pidana penataan ruang belum satupun perkara yang dapat diselesaikan melalui peradilan pidana yang ada di pusat maupun di daerah. Mereka masih menggunakan penyelesaian secara administratif dan keperdataan apabila terjadi pelanggaran penataan ruang yang lebih populer untuk digunakan. Hal ini menunjukkan adanya indikasi berbagai kelemahan pada kelembagaan maupun pemberdayaan PPNS-PR di pusat maupun di daerah, yang secara konkrit sangat sulit mengimplementasikan tugas dan fungsinya. ${ }^{25}$

Selain itu, secara garis besar ada beberapa hal yang perlu diperhatikan dalam hal penegakan hukum yang dilakukan oleh PPNS-PR. Upaya penegakan hukum oleh PPNS-PR tentu akan menemui berbagai kendala yang dihadapi dalam upaya melaksanakan kewenangannya sebagaimana ditentukan dalam peraturan perundang-undangan. Misalnya dalam hal belum tersedianya perangkat instrumen pengendalian pemanfaatan tata ruang yang memadai di daerah. Hal ini dapat diketahui hanya dari beberapa provinsi dan kabupaten/ kota saja yang telah mengesahkan RTRW. Permasalahan ini akan menimbulkan berbagai aktifitas penyimpangan atau pelanggaran yang terjadi dan mengakibatkan sulitnya untuk menanggulangi dengan responsif karena produk rencana tata ruang seringkali belum memadai sebagaimana dikehendaki oleh peraturan perundang-undangan yang ada. Oleh karena produk tata ruang yang belum memadai, maka akan sulit bagi PPNS-PR dalam melaksanakan tugasnya dalam penegakan hukumnya.

Penegakan hukum yang dilakukan PPNSPR juga akan menemui kesulitan dikarenakan sistem kepegawaian dan kelembagaan PPNS-PR itu sendiri. Status kepegawaian seorang PPNSPR diangkat oleh pemerintah, pada tingkatan provinsi diangkat oleh gubernur, sedangkan pada tingkatan kabupaten/kota oleh bupati/walikota. Sistem Pengangkatan kepegawaian ini termasuk dalam jenjang karir dan kepangkatannya ditentukan oleh kepala daerahnya masingmasing. Sistem pengangkatan kepegawaian ini menimbulkan kesulitan bagi PPNS-PR sendiri dalam melaksanakan tugas dan kewenangannya. Misalnya apabila pelanggaran penataan ruang itu dilakukan oleh kepala daerah baik gubernur maupun bupati/walikota, maka PPNS-PR tidak akan mampu melaksanakan kewenangannya. Apabila hal ini terjadi, maka kesulitan bagi PPNS-PR karena proses penyidikan terhadap tersangka oleh PPNS-PR adalah atasannya sendiri (gubernur dan bupati/walikota). Dengan status kepegawaian itulah, maka PPNS-PR

25 Data Hasil survei Kementerian Agraria dan Tata Ruang Tahun 2015. 
diangkat dan diberhentikan oleh atasannya (gubernur dan bupati/walikota). Oleh karena status kepegawaian yang melekat sebagai pegawai negeri sipil dalam pemerintahan, sehingga kepala daerah dapat saja dengan kebijakannya merotasi atau memutasikan maupun pemberhentian terhadap PPNS$\mathrm{PR}$, karena statusnya sebagai pegawai negeri sipil. Pada akhirnya dapat diketahui bahwa di daerah kekurangan PPNS-PR, sehingga PPNSPR di daerah belum sesuai secara proporsional dengan luas wilayah yang menjadi teritorialnya.

Eksistensi PPNS-PR sebagai penyidik di bidang penataan ruang dalam penegakan hukum masih juga mengalami hambatan, misalnya tidak tersedianya unit kerja secara kelembagaan yang khusus mewadahi PPNS-PR dalam pelaksanaan tugas dan fungsi PPNS-PR. Permasalahan semakin kompleks Karena PPNSPR yang ada masih tersebar diberbagai Satuan Kerja Perangkat Daerah (SKPD yaitu perangkat daerah pada pemerintah daerah baik di tingkat provinsi maupun kabupaten/kota), mereka sudah sangat dibebani dengan tugas pokok pada unitnya masing-masing. Hal ini terjadi, karena tidak adanya sistem kelembagaan yang baik bagi PPNS-PR, yang seharusnya berada di bawah satu wadah kelembagaan yang tersusun secara sistematis dan berjenjang dari pusat ke daerah.

Permasalahan yang juga masih merupakan hambatan bagi PPNS-PR dalam kaitannya sebagai upaya dalam penegakan hukum di bidang penataan ruang, yaitu tidak tersedianya unit kerja secara kelembagaan yang khusus melakukan pembinaan, pemberdayaan dan pengawasan PPNS-PR. Hal ini dapat ditunjukkan bahwa, PPNS-PR baik yang berada di pusat maupun di daerah tidak mendapatkan perhatian dalam pengembangan kemampuan khusus penyidikan. Pembekalan dan pembinaan bagi PPNS-PR di bidang penyidikan yang terbatas dan tidak berjenjang, sehingga mengakibatkan kurangnya kemampuan dalam penyidikan.

Selain masalah pengembangan kemampuan penyidikan juga masalah pelaksanaan tugas dan fungsi PPNS-PR tidak optimal, karena mereka kebanyakan berada di bawah unit kerja yang tidak sejalan dengan tugasnya sebagai penyidik. PPNS-PR seringkali berada di Bapedda bidang ekonomi, bidang perhubungan, pariwisata, pendidikan, satpol PP dan dinas-dinas lainnya yang tidak relevan. Oleh karena berada di dinas lainnya, maka kinerja PPNS-PR seringkali tidak terpantau prestasinya karena tidak ada lembaga yang berwenang melakukan pengawasan dan evaluasi termasuk pembinaan. Oleh karena tidak adanya sistem kelembagaan yang baik, maka dalam hal pembinaan dan pengembangan kemampuan PPNS-PR belum tersedianya rencana atau program kerja yang jelas bagi PPNS-PR baik yang berada di pusat maupun di daerah, mengakibatkan tugas, fungsi dan kewenangan PPNS-PR dalam penegakan hukum di bidang penataan ruang tidak dapat terealisasi dengan baik dan berkesinambungan. Oleh karena tidak adanya kelembagaan yang baik, maka juga tidak ada anggaran khusus untuk membiayai keberadaan PPNS-PR tersebut, sehingga menyulitkan PPNS-PR dalam melaksanakan kewenangannya.

Masalah yang juga penting bagi PPNS-PR dalam menjalankan tugas dan kewenangannya adalah perangkat perlindungan hukum bagi PPNS-PR yang tidak tersedia, karena peraturan perundang-undangan yang memberikan eksistensi PPNS di bidang penegakan hukum penataan ruang tidak memberikan perlindungan. Oleh karena tidak adanya perangkat perlindungan hukum bagi PPNS-PR 
semestinya ini menjadi perhatian pemerintah karena PPNS-PR dalam menjalankan tugas penegakan hukum selalu terkait dengan konflik vertikal maupun horizontal yaitu permasalahan yang ada di masyarakat dan permasalahaan yang berasal kebijakan pemerintah, yang kemudian akan mengancam kedudukan sebagai pegawai negeri sipil maupun penyidik pegawai negeri sipil bidang penataan ruang.

Masalah yang masih mempengaruhi PPNSPR dalam upaya melakukan penegakan hukum adalah adanya overlapping kewenangan dalam penegakan hukum. Sebagai contoh dalam upaya penegakan hukum di bidang penataan ruang selain PPNS-PR juga ada beberapa instansi atau lembaga yang dapat melaksanakan penertiban terhadap pelanggaran pemanfaatan ruang yaitu Badan Koordinasi Penataan Ruang Daerah (BKPRD), instansi penerbit izin, maupun instansi atau lembaga lain yang bertugas dalam penertiban. Oleh karena berhubungan dengan pemerintahan yang dijalankan oleh pemerintah, sehingga semua kendala yang berkaitan dengan penegakan hukum di bidang penataan ruang yang dilakukan oleh Penyidik Pegawai Negeri Sipil tidak mendapat respon dan tanggapan serta perbaikan oleh pemerintah. Pemerintah masih mempunyai kepentingan yang besar terhadap pengelolaan sumber daya alam dengan tidak memperhatikan dampak lingkungan, sehingga pelanggaran terhadap penataan ruang belum mendapat respons yang baik. Di sinilah seharusnya dukungan atau kemauan politik pemerintah yang diperlukan.

Upaya penegakan hukum yang dilakukan oleh PPNS-PR ini tidak akan maksimal, apabila beberapa kendala yang dihadapi oleh PPNSPR itu sendiri belum dapat terselesaikan. Penegakan hukum berkaitan dengan berbagai aspek yang cukup kompleks, dengan tujuan tetap mempertahankan dan menciptakan tata ruang yang dapat dinikmati oleh setiap manusia dalam pengertian luas dengan tidak mengganggu lingkungannya itu sendiri. Dalam menjaring sikap para pihak yang tidak bertanggung jawab telah diciptakan berbagai bentuk peraturan perundang-undangan dengan bentuk undang-undang dan berbagai peraturan pelaksanaannya.

\section{Penutup}

Pemerintah masih belum berupaya untuk menciptakan penataan ruang yang nyaman dan menumbuhkan kesadaran masyarakat, sehingga penyelenggaraan penataan ruang masih belum sesuai dengan peraturan perundangundangan yang ada. Institusi PPNS-PR yang diberi kewenangan untuk melaksanakan penegakan hukum terutama dalam hal terjadinya pelanggaran penataan ruang tidak banyak berbuat maksimal karena permasalahan eksistensinya dalam sistem penegakan hukum di bidang penataan ruang.

Melihat kenyataan yang ada dapat dikatakan bahwa terdapat beberapa hal penting yang harus segera dilakukan (oleh kemauan negara) dalam rangka memperkuat eksistensi PPNSPR. PPNS-PR masih mengalami hambatan dan tidak maksimal dalam upaya melakukan kewenangannya yaitu upaya penegakan hukum apabila terjadi pelanggaran di bidang penataan ruang. Permasalahan yang menjadi hambatan dan tidak maksimalnya PPNS-PR dalam upaya melakukan penegakan hukum adalah tidak adanya perangkat peraturan yang lebih rinci mengenai kelembagaan dan status kepegawaian PPNS-PR yang secara definitif yang berada di pusat maupun di daerah, fasilitas (sarana dan prasarana) tidak ada, program kerja yang tidak terencana, anggaran yang tidak jelas, tidak 
adanya pendidikan dan pembinaan anggota PPNS yang professional serta tidak adanya kemitraan strategis dengan aparat kepolisian dan instansi lainnya. Dengan permasalahan ini, maka tidak adanya politik pemerintah dalam rangka memperbaiki dan memperkuat eksistensi PPNS-PR.

Oleh karena itu untuk memperkuat eksistensi PPNS di bidang penataan ruang perlu dilakukan beberapa hal di antaranya:

a. Membuat perangkat peraturan perundangundangan lebih rinci yang menunjukkan kelembagaan dan status kepegawaian PPNSPR secara definitif, sehingga keberadaannya dapat saja berada di pusat maupun di daerah.

b. Fasilitas (sarana dan prasarana) yang memadai dalam rangka untuk melaksanakan kewenangannya dan dukungan anggaran yang jelas dalam rangka penegakan hukum terhadap pelanggaran tata ruang.

c. Perlunya mempersiapkan program kerja yang terencana dalam upaya penegakan hukum.

d. Perlunya mempersiapkan personil/anggota PPNS penataan ruang yang profesional dengan bekal pendidikan dan pembinaan yang mapan dan berkualitas.

e. Menjalin kemitraan strategis dengan pihak kepolisian, kejaksaan, lembaga peradilan, dinas terkait, dan lembaga swadaya masyarakat, dengan tujuan untuk memperkuat koordinasi dalam upaya penegakan hukum bidang penata ruang.

\section{Daftar Pustaka}

\section{Buku}

Gustian, Dedi, dkk, dalam Politik Ruang dan Perlawanan: Kisah Konflik Atas Ruang Pada
Tingkat Lokal (Bogor: Jaringan Kerja Pemetaan Partisipatif, 2014).

Hamzah, Andi, Hukum Acara Pidana Indonesia (Jakarta: Sinar Grafika, 2008).

Hardjasoemantri, Koesnadi, Hukum Tata Lingkungan Edisi VIII (Yogyakarta, Gadjah Mada University Press, 2006).

Hartono, Penyidikan dan Penegakan Hukum Pidana Melalui Pendekatan Hukum Progresif (Jakarta: Sinar Grafika, 2010).

Hasni, Hukum Penataan Ruang dan Penatagunaan Tanah, Dalam Konteks UUPA, UUPR, UUPLH (Jakarta: Rajawali Press, 2013).

Hadjon, Philipus M, Pengantar Hukum Administrasi Indonesia (Yogyakarta: Gadjah Mada University Press, 2002).

Karjadi, M. dan R. Soesilo, Kitab Undang-Undang Hukum Acara Pidana dengan Penjelasan Resmi dan Komentar (Bogor: Politeia, 1997).

Rasjidi, Lili dan Liza Sonia Rasjidi, Monograf: Filsafat IImu, Metode Penelitian, Dan Karya Tulis IImiah Hukum Bandung, 2009.

Ridwan HR, Hukum Administrasi Negara (Jakarta: Raja Grafindo Persada, 2006).

Ridwan, Juniarso dan Achmad Sodik, Hukum Tata Ruang Dalam Konsep Kebijakan Otonomi Daerah (Bandung: Nuansa, 2013).

Soekanto, Soerjono dan Sri Mamudji, Penelitian Hukum Normatif Suatu Tinjauan Singkat (Jakarta: Raja Grafindo Persada, 2006).

Sukardja, Ahmad, Hukum Tata Negara dan Hukum Administrasi Negara Dalam Perspektif Fikih Siyasah (Jakarta: Sinar Grafika, 2012).

Wahid, A.M. Yunus, Pengantar Hukum Tata Ruang (Jakarta: Prenadamedia, 2014).

\section{Makalah/Artikel/Laporan/Hasil Penelitian}

Data Hasil survei Kementerian Agraria dan Tata Ruang Tahun 2015.

Manan, Bagir, "Pembinaan Hukum Nasional" (disampaikan untuk kuliah umum di Fakultas Hukum Universitas Padjadjaran, Bandung, 18 Agustus 1997).

Nasution, Bahder Johan, "Upaya Penerapan Sanksi Administratif Dan Perizinan Sebagai Pembatasan Terhadap Kebebasan Bertindak" (dalam Jurnal Ilmu Syariah dan Hukum Asy-Syir'ah, Vol. 48, No. 1, Juni 2014).

Rajagukguk, Erman, "Perlu Pembaharuan Hukum dan Profesi Hukum" (Pidato Pengukuhan Sebagai Guru Besar Hukum, Suara Pembaruan). 


\section{Internet}

Indonesian Institute for Infrastructure Studies, "Ketentuan Pengendalian Pemanfaatan Ruang Wilayah Kabupaten", Indonesian Institute for Infrastructure Studies, http:// www.penataanruang.com/pengendalianruang2.html (diakses 21 Mei 2017).

Indonesian Institute for Infrastructure Studies, "Arahan Sanksi", Indonesian Institute for Infrastructure Studies, http://www. penataanruang.com/sanksi.html (diakses 21 Mei 2017).

Ismail Zubir, "Penyimpangan Tata Ruang", KALPATARU, https://imazu.wordpress. com/2008/01/09/penyimpangan-tataruang/ (diakses 19 Mei 2017).

Raflis, "Tata Ruang dan Korupsi", Transparency International Indonesia, https:// a dvokasitataruang. files.wordpress. com/2011/09/tata-ruang-dan-korupsi.pdf (diakses 20 Juli 2017).

\section{Peraturan}

Undang-Undang Nomor 26 Tahun 2007 tentang Penataan Ruang.

Undang-Undang Nomor 32 Tahun 2009 tentang Perlindungan dan Pengelolaan Lingkungan Hidup.

Undang-Undang Nomor 23 Tahun 2014 tentang Pemerintahan Daerah.
Undang-Undang Nomor 2 Tahun 2002 tentang Kepolisian Negara Republik Indonesia.

Undang-Undang Nomor 8 Tahun 1981 tentang Hukum Acara Pidana.

Peraturan Pemerintah Nomor 43 tahun 2012 tentang Tata Acara Pelaksanaan Koordinasi, Pengawasan, dan Pembinaan Teknis Terhadap Kepolisian Khusus, Penyidik Pegawai Negeri Sipil dan Bentuk-bentuk Pengamanan Swakarsa.

Peraturan Pemerintah Nomor 58 Tahun 2010 tentang Perubahan Atas Peraturan Pemerintah Nomor 27 Tahun 1983 Tentang Pelaksanaan Kitab Undang-Undang Hukum Acara Pidana.

Peraturan Menteri Dalam Negeri No. 41 Tahun 2010 tentang Organisasi dan Tata Kerja Kementerian Dalam Negeri.

Peraturan Menteri Pekerjaan Umum Nomor 13/ PRT/M/2009 tentang Penyidik Pegawai Negeri Sipil Penataan Ruang.

Peraturan Menteri Hukum dan HAM No. M.HH.01. AH.09.01 TAHUN 2011 Tentang Tata Cara Pengangkatan, Pemberhentian, Mutasi, Dan Pengambilan Sumpah atau Janji Pejabat PenyidikPegawai Negeri Sipil, Dan Bentuk, Ukuran, Warna, Format, Serta Penerbitan Kartu Tanda Pengenal Pejabat Penyidik Pegawai Negeri Sipil.

Keputusan Menteri Dalam Negeri No. 7 Tahun 2003 tentang Pedoman Operasional Penyidik Pegawai Negeri Sipil Daerah Dalam Penegakan Peraturan Daerah. 